\title{
The economic impact of COVID-19 in Colombia
}

Laura Bolton

Institute of Development Studies

26 February 2021

\section{Question}

What is the economic impact of COVID-19 in Colombia, specifically with respect to trends in agriculture, infrastructure and public procurement? Highlight the impact on women, low-income groups and marginalised groups.

\section{Contents}

1. Summary

2. The economy in Colombia since the outbreak of COVID-19

3. Impact on different groups

4. Agriculture

5. Infrastructure

6. Public procurement

7. References

The K4D helpdesk service provides brief summaries of current research, evidence, and lessons learned. Helpdesk reports are not rigorous or systematic reviews; they are intended to provide an introduction to the most important evidence related to a research question. They draw on a rapid deskbased review of published literature and consultation with subject specialists.

Helpdesk reports are commissioned by the UK Foreign, Commonwealth, and Development Office and other Government departments, but the views and opinions expressed do not necessarily reflect those of FCDO, the UK Government, K4D or any other contributing organisation. For further information, please contact helpdesk@k4d.info. 


\section{Summary}

Available data provides a picture for the macro-economy of Colombia, agriculture and infrastructure. Recent data on trends on public procurement were difficult to find within the scope of this rapid review.

In 2020, macro-level employment figures show a large drop between February and April when COVID-19 lockdown measures were first introduced, followed by a gradual upward trend. In December 2020, the employment rate was 4.09 percentage points lower than the employment rate in December 2019.

Gender differences: Macro-level figures from the National Administrative Department of Statistics (DANE) shows that a higher percentage of men experienced job losses than women in November 2020. However, evidence presented by the Universidad Nacional de Colombia based on the DANE great integrated house survey shows that a higher proportion of all jobs lost were lost by women in the second quarter. It may be that the imbalance shifted over time but it is not possible to directly compare the data. Evidence suggests that women were disproportionately more burdened by home activities due to the closure of schools and childcare. There is also a suggestion that women have lost out where jobs able to function during lockdowns with technology are more likely to be held by men. Literature also shows that women have lower levels of technology literacy.

There is a lack of reliable data for understanding the economic impacts of COVID-19 for people living with disability. A report on the COVID-19 response and disability for the Latin America region recommends improving collaboration between policy makers and non-governmental organisations (Meresman \& Ullman, 2020).

Younger people experienced greater job losses. Data for November 2020 show 3.3 percent of the population aged under 25 lost their job compared to 1.8 percent of those employed between 24 and 54.

Agriculture, livestock and fishing increased by $2.8 \%$ in 2020 compared to 2019 . And the sector as a whole grew $3.4 \%$ between the third and fourth quarter of 2020 .

Between 2020 and 2019 the construction sector contracted by 27.7\% (DANE, 2021). And contracted $0.2 \%$ from the third to the fourth quarter.

In terms of sector differences, construction was harder hit by the initial mobility restrictions than agriculture. Construction contracted by $30.5 \%$ in the second quarter of 2020 . It is making a relatively healthy recovery with reports that $84 \%$ of projects being reactivated following return to work. The President of the Colombian Chamber of Construction predicting an $8.4 \%$ growth in the construction of housing and other buildings in 2021.

Agriculture was reported to be one of the sectors least affected by the shock. The primary sector (which includes agriculture) contracted monthly between March and December 2020 decreasing by around $10 \%$ each month. A greater proportion of men work in agriculture than women.

Information on public procurement since COVID-19 describes the successful use of eProcurement systems. An open call by the government for essential supplies allowed a greater 
range of suppliers to respond to COVID-19 needs increasing efficiency, transparency and monitoring.

\section{The economy in Colombia since the outbreak of COVID- 19}

Confinement policies aimed at reducing the spread of COVID-19 in March to August 2020 had an impact on all sectors of the economy but mainly affecting commerce, transport, tourism and industry sectors (Meija et al., 2021). Selective isolation and flexibility in mobility restrictions after August has allowed productive activities an upward trend. In the second quarter of 2020 the Colombian economy fell at an annual rate of $-15.8 \%$, and fell by $-9.0 \%$ in the third quarter. The reduction in the third quarter was attributed to the sectors commerce, repair, transport, accommodation and food services, construction, and mining.

Compared to 2019 , fourth quarter gross domestic product (GDP) decreased by $3.6 \%$. For the year as a whole 2020 GDP decreased by 6.8\% compared to 2019 (DANE, 2021). Retail, transport and services activities contributed 3.0 percentage points to the GDP fall, Construction $1.9 \%$ and mining activities $1.0 \%$.

Figure 1 shows the pattern of employment rate before and following the COVID-19 outbreak across all sectors (Banco de la República, 2020a). Between February to April the employment rate dropped from $55.48 \%$ to $41.57 \%$. It has risen gradually to around $53 \%$ in October where it has plateaued. In 2019 the employment rate in December was $57.50 \%$ and $53.41 \%$ in December 2020, a year-on-year percentage point difference of -4.09 .

$2.3 \%$ of dependent jobs registered retirements in November 2020 , compared to $2.1 \%$ in November 2019 (DANE, 2020a). There was a 5.9\% decrease in the dependent labour market and $4.0 \%$ decrease in the independent labour market in 2020 compared to 2019.

Figure 1: Employment rate in Colombia 2019-2020

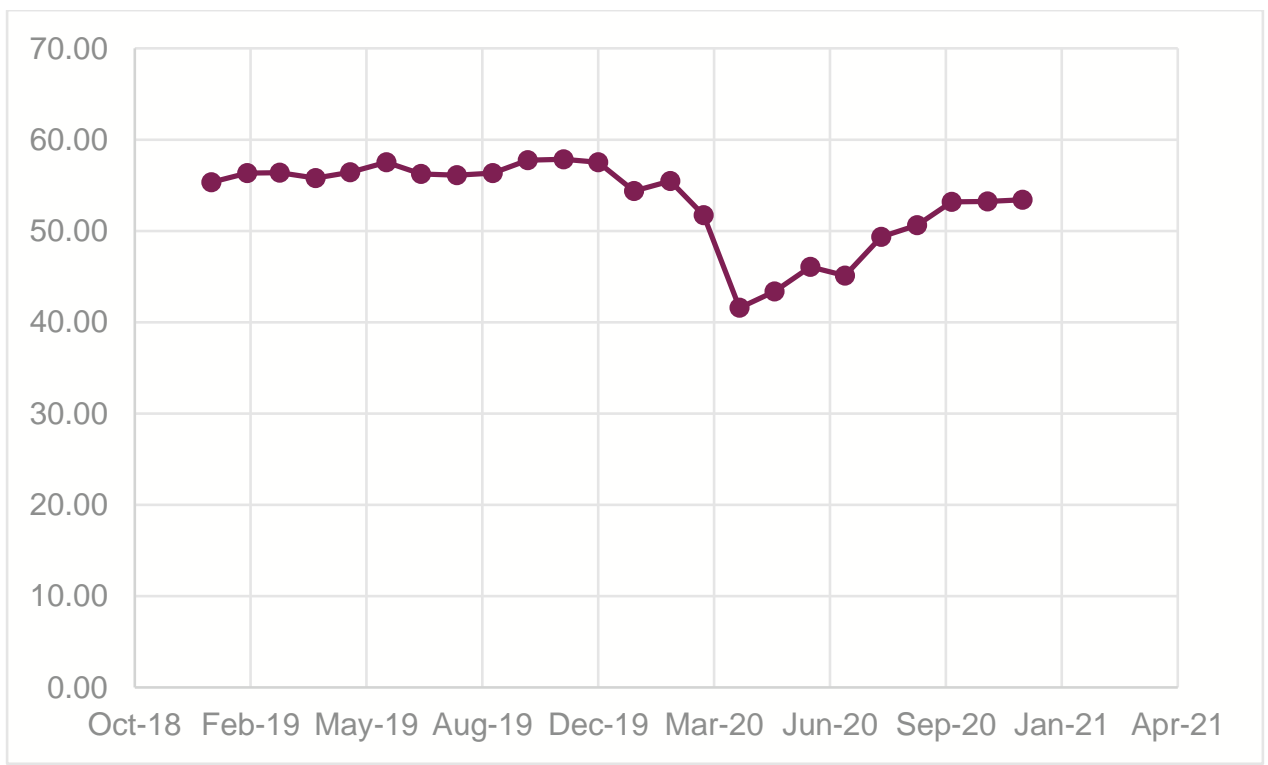

Data source: Banco de la República. (2020a). 


\section{Impact on different groups}

\section{Gender}

Employment data show that overall a higher proportion of men have experienced job losses compared to women. In November $20202.5 \%$ of men had their contracts suspended compared with $2.1 \%$ of women (DANE, 2020a). In November 2019, the same statistic was $1.13 \%$ for men and $1.01 \%$ for women.

Looking at it from a perspective of proportions of jobs lost gives a different picture. Second quarter statistics from the Universidad de los Andes reports states that women represented a greater proportion of jobs lost than men (Beccerra et al., 2020). Of all jobs lost $52.08 \%$ were lost by women, and $47.92 \%$ were lost by men, despite women making up a smaller proportion of the labour market (40\%). Female unemployment in the second quarter of 2019 was $12.9 \%$ and a year later, the second quarter of $2020,24.6 \%$. The report also suggests a reassignment of care responsibilities and work participation within the home.

A survey by DANE and El futuro es de todos in August 2020 found that $39.6 \%$ of women felt more burdened with home activities, compared to $20.0 \%$ of men compared to before the start of preventive isolation (Herrera-Idárraga et al., 2020). Closure of schools has meant that unpaid workload has increased and a larger proportion of women (89.5\%) participate in unpaid care activities than men (62.0\%) (Consejeria Presidencial para la Equidad de la Mujer, 2020). Also, a majority of women work in sectors most affected by social distancing such as hospitality, commerce, and restaurant services. The incidence of this factor is suggested to be lower than the factor of status in the home regarding childcare activities and the presence of children (Becerra et al., 2020). The Universidad de los Andes report states that data indicates that female employment recovery is dependent on schools and care centers resuming services.

Potentially women are more excluded as jobs reconfigure around technologies due to confinement policies. Women have less access and ability with these technologies in Colombia than men with $19 \%$ of women between ages 15 to 49 not overcoming the gap in access and use of ICT use (38\% in the case of rural women) (Consejeria Presidencial para la Equidad de la Mujer, 2020). Women are more likely to be in jobs that are unable to reconfigure in this way, such as jobs requiring routine tasks which are more exposed to job loss.

\section{Disability}

A report on COVID-19 and people with disabilities in Latin America ${ }^{1}$ highlights lack of reliable data as a challenge in understanding and supporting this group (Meresman \& Ullman, 2020). There are no key indicators to check whether adaptations and adjustments have been implemented for this group including access to decent work. The report finds efforts by governments in the region to respond inclusively but "presents a predominantly negative assessment of the measures taken and a pessimistic perception about the scenarios to come for

\footnotetext{
${ }^{1}$ Data specifically on Colombia may be contained in this report but was unable to translate in to English https://repositorio.cepal.org/bitstream/handle/11362/46278/S2000645_es.pdf?sequence=1\&isAll owed=y
} 
the population with disabilities" (Meresman \& Ullman, 2020, p9). The report recommends improved collaboration between those implementing policies and related non-governmental organisations. $^{2}$

\section{Age}

The younger section of the labour market in Colombia has been more affected by job losses (DANE, 2020a). In November 2020, 3.3\% of the employed population aged under 25 lost their jobs compared to $2.2 \%$ of those employed between 25 and 54 , and $1.8 \%$ of employed people over 55. In November of the previous year the job loss rates for these ages were $0.90,1.08$, and $1.56 \%$ respectively.

\section{Region}

Regional variations are identified with lower economic contraction in the Pacific, Central and Bogotá regions and more pronounced contractions in the Amazon-Orinoquía, Eastern and Caribbean regions (Meija et al., 2021).

\section{Low-income groups}

Innovations for Poverty Action (IPA) conducted a survey ${ }^{3}$ in Colombia in May 2020 in partnership with Colombia's National Planning Department to assess employment situations and guide decision making for response (Chaskel and Holloway, 2020) ${ }^{4}$. From 1,500 households approximately $50 \%$ of those who had worked in February had not worked in May. Of those that were still working, $21 \%$ were earning less. Approximately half of Colombia's workers are hired informally and are more vulnerable to shocks. Among employees surveyed, only $26 \%$ of informal workers had worked in the past week, compared to $49 \%$ of formal workers. There are concerns that improvements made in the past two decades towards poverty alleviation are being reversed.

A second round of the IPA survey interviewed 1,000 households in August 2020 (IPA, 2020). $64 \%$ of respondents reported that their debts had increased, a larger proportion of these having informal jobs.

\section{Agriculture}

Agriculture, livestock and fishing grew by $2.8 \%$ in 2020 compared to 2019 (DANE, 2021). This reflects a $4.8 \%$ growth in agricultural crops and livestock; $10.5 \%$ decrease in coffee crop growth; $1.7 \%$ increase in livestock; $1.6 \%$ increase in forestry and timber extraction; and $22 . \%$ growth in

\footnotetext{
2 The report includes survey results from Colombia which were not possible to translate into English and were not possible to include in this report. Section D looks at access to work and economic activity. https://repositorio.cepal.org/bitstream/handle/11362/46278/S2000645_es.pdf?sequence=1\&isAllowed=y

3 The survey intended to be of use to measure the impacts of COVID-19 on people living in poverty in low- and middle-income countries. Sampling methods are not described. https://www.poverty-action.org/questionnaire/iparecovr-survey

${ }^{4}$ A blog style report of survey results
} 
fishing and aquaculture. The sector as a whole grew $1.3 \%$ between the third and fourth quarter in 2020. And the sector as a whole grew 3.4\% between the third and fourth quarter of 2020.

In October 2020 a Monetary Policy Report notes that agriculture was among the sectors least affected by the shock and was expected to show positive growth in the third quarter (Banco de la República, 2020b).

Economic tracking indicators show the primary sector (which includes agriculture of agriculture, livestock; hunting; forestry and fishing, and extraction from mines and quarries) contracted by 10.68\% in November 2020 (DANE, 2020b). In November 2019, the same sector had grown by $2.63 \%$. It showed a contraction each month in 2020 from March to November. The smallest contraction was in March, 1.8\% The largest contraction was in April, $11.43 \%$.

Prices for agricultural products saw marked drops at the beginning of the pandemic. A report from DANE (2020a) describes price drops experienced in May 2020 including a $23.3 \%$ fall in the price for spinach, $12.44 \%$ for tomato, $20 \%$ for pumpkin, $11.1 \%$ for mandarin, $35.59 \%$ for potato and an increase of $16.23 \%$ for lettuce. There are different factors affecting these prices for example, cargo restrictions have reduced access for buyers.

Impacts associated with this sector may vary by gender as $22.5 \%$ of men work in agriculture and $6.7 \%$ of women (Consejeria Presidencial para la Equidad de la Mujer, 2020). Impacts on other groups were not identified.

\section{Infrastructure}

Between 2020 and 2019 the construction sector contracted by 27.7\% (DANE, 2021). And contracted $0.2 \%$ from the third to the fourth quarter.

The first quarter of 2020 saw a fall in constructions GDP measurement by 9.4\% (KPMG, 2020). The second quarter saw a contraction in every sector of the economy due to social distancing and quarantine measures. The largest declines were in components directly affected by social distancing of which construction was one, contracting by 30.5\% (Banco de la República, 2020b). ${ }^{6}$ Within this component, building construction performed better than projected but the fall in public works construction was much bigger than expected. The Colombia chamber of construction reported that once allowed to return to work, 84\% of projects were activated (KPMG, 2020).

The buildings and structures sub-category is expected to contribute to improvements within gross fixed capital formation ${ }^{7}$. This is due to the continuation of multiple road infrastructure projects and other works, particularly in Bogotá. The October 2020 Monetary Policy Report considers construction to be one of the sectors to have likely "most benefited from the flexibilization or

\footnotetext{
${ }^{5}$ Likely as compared to the previous month although the report does not specify.

${ }^{6}$ The sectors seeing larger declines were arts, entertainment, and recreation (-37.1\%); and trade, repairs, transport, and lodging (-33.9\%).

${ }^{7}$ Gross fixed capital formation consists of resident producers' investments, deducting disposals, in fixed assets during a given period. https://ec.europa.eu/eurostat/statisticsexplained/index.php/Glossary:Gross_fixed_capital_formation_(GFCF)
} 
quarantine measures and the partial recovery of demand" (Banco de la República, 2020b, p22). Particularly in public works.

A recent news article reports the President of the Colombian Chamber of Construction predicting an $8.4 \%$ growth in the construction of housing and other buildings in 2021 but not infrastructure projects (Bocanegra, 2021). The government is reported to be progressing with plans for a fifth round of concessions (5G programme) including road, rail, river, and airport projects.

$11 \%$ of men work in construction compared to $1 \%$ of women (Consejeria Presidencial para la Equidad de la Mujer, 2020). Data on the impact on other groups was not identified.

The Monetary Policy Report from the Banco de la República (2020b) states that "investment in public works should continue to increase thanks primarily to a partial recovery in construction (especially in public works and social housing)" (p21). This growth is starting from a low level so will not prevent a fall in annual terms.

\section{Public procurement}

During the pandemic Colombia's public procurement agency has adapted public procurement tools to meet new demands, to secure essential supplies such as personal protective equipment according to a Digital Buying Guide case study (Colombia Compra Eficiente, 2020). The urgency of the pandemic threatened to compromise careful reform that had been made to improve transparency and accountability in procurement. Approvals and fundraising needed to be fast tracked. Buyers were encouraged to use the Colombia Compra Eficiente (CCE) ${ }^{8}$ eProcurement platform. The system is thought to provide a tool for integrity and efficiency as well as highquality performance monitoring (Open Contracting, 2020). Anyone can track the country's COVID-19 procurement purchases. New digital tools, such as an aggregate buying device ${ }^{9}$, have allowed CCE to streamline buying during the pandemic and also enables transparency (Colombia Compra Eficiente, 2020).

The aggregate demand instrument allowed a pool of suppliers to be hired with general conditions and price caps set, whilst quantities and prices were finalised later at the time of the purchase order (Open Contracting, 2020). An open call by the government was put out for suppliers allowing those that had not worked with the government before a chance to bid. The broader supplier base meant more information on prices, quality and supply options in a market where distortion and information asymmetries are an issue.

No trend data on public procurement was identified.

\footnotetext{
${ }^{8}$ Colombia's public buying agency

${ }^{9}$ COVID-19 Emergency Demand Aggregation Instrument https://www.colombiacompra.gov.co/tienda-virtual-delestado-colombiano/salud/instrumento-de-agregacion-de-demanda-emergencia-covid-19
} 


\section{References}

Banco de la República (2020a). Employment and unemployment rates - Percentage of workforce.

https://totoro.banrep.gov.co/analytics/saw.dll?Download\&Format=excel2007\&Extension=.xlsx\&B ypassCache=true\&path=\%2Fshared\%2fSeries\%20Estad\%c3\%adsticas_T\%2F1.\%20Empleo\%2 Oy\%20desempleo\%2F1.1\%20Serie\%20hist\%C3\%B3rica\%2F1.1.1.EMP_Total\%20nacional\%20I QY\&lang=es\&NQUser=publico\&NQPassword=publico123\&SyncOperation=1

Banco de la República (2020b). Monetary Policy Report, 10/2020.

https://repositorio.banrep.gov.co/bitstream/handle/20.500.12134/9975/monetary-policy-reportoctober-2020. pdf? sequence $=1$ \&isAllowed $=\mathrm{y}$

January 2021 version available in Spanish:

https://repositorio.banrep.gov.co/bitstream/handle/20.500.12134/9974/IPM_ENE\%20202

1_final.pdf?sequence $=1$ \&isAllowed=y

Beccerra, O., Eslava, M., Fernández, M., Isaacs, M., \& Perez-Reyna, D. (2020). Empleo femenino durante la crisis del COVID-19. Noviembre 2020. Universidad de los Andes, Nota Macroeconómica No.28. https://repositorio.uniandes.edu.co/handle/1992/47881

Bocanegra, N. (2021). Colombia's construction industry sees light at end of tunnel in 2021. Reuters. https://www.reuters.com/article/us-colombia-construction-idUSKBN2AP2Q3

Colombia Compra Eficiente (2020). Emergency buying: Colombia's digital approach to COVID19. Digital Buying Guide. https://www.digitalbuyingguide.org/en/case-studies/emergency-buyingcolombias-digital-approach-to-covid-19/

Consejeria Presidencial para la Equidad de la Mujer (2020). The COVID-19 crisis: differential impact and challenges for women in Colombia.

http://www.observatoriomujeres.gov.co/archivos/publicaciones/Publicacion_37.pdf

DANE (2021). Technical Bulletin Gross Domestic Product (GDP) IV quarter 2020.

https://www.dane.gov.co/files/investigaciones/boletines/pib/bol_PIB_IVtrim20_producion_y_gast o.pdf

DANE (2020a). Labor market perspectives from the statistical register of labor relations (RELAB) November 2020.

https://www.dane.gov.co/files/investigaciones/boletines/ech/ech/CP_RELAB_empleo_nov_20.pdf

DANE (2020b). Report on wholesale prices and supply in the health situation due to COVID-19. https://www.dane.gov.co/files/investigaciones/agropecuario/sipsa/emergencia-sanitaracovid19/informe-bogota-covid19-29-may-2020.pdf

Herrera-Idárraga, P., Bonilla, H.M.H., Rubio, T.G., Ramírez-Bustamante, N., Tribin, A.M., Garzón, T.C., \& Grupo de Enfoque Diferencial e Interseccional Dirección General del DANE (2020). Informe sobre cifras de empleo y brechas de género. Cambios en el empleo en actividades de cuidado remunerado a raíz del COVID-19.

https://www.dane.gov.co/files/investigaciones/boletines/ech/Informe-sobre-cifras-de-empleo-ybrechas-de-genero-10-2020.pdf 
IPA (2020). Colombia RECOVR Survey Round 2. https://www.povertyaction.org/sites/default/files/Round\%202_Colombia_English_For\%20Website.pdf

KPMG (2020). Impacts of COVID-19, Infrastructure.

https://assets.kpmg/content/dam/kpmg/co/pdf/2020/09/kpmg-co-impactos-del-covid-19infraestructura.pdf

Meija, L.F., Rojas, M.E.D., Gallego, A.F., Lopez, D., Garcia, T. (2021). Quarterly Report Bulletin: Sectorial and Regional Perspectives. Fedesarrollo.

http://dams.fedesarrollo.org.co/iml/publicaciones/informe-trimestral-perspectivas-sectoriales-yregionales-isr-febrero-2021/

Meresman, S. \& Ullman, H. (2020). COVID-19 and people with disabilities in Latin America. Mitigate the impact and protect rights to ensure inclusion today and tomorrow. CEPAL.

https://repositorio.cepal.org/bitstream/handle/11362/46278/S2000645_es.pdf?sequence=1\&isAll owed=y

Open Contracting (2020). Open for business: Colombia's data-driven procurement reforms increase competition. Open Contracting blog. https://www.open-

contracting.org/2020/07/16/open-for-business-colombias-data-driven-procurement-reformsincrease-competition/

\section{Suggested citation}

Bolton, L. (2021). The economic impact of COVID-19 in Colombia. K4D Helpdesk Report 971.

Brighton, UK: Institute of Development Studies. DOI: 10.19088/K4D.2021.073

\section{About this report}

This report is based on six days of desk-based research. The K4D research helpdesk provides rapid syntheses of a selection of recent relevant literature and international expert thinking in response to specific questions relating to international development. For any enquiries, contact helpdesk@k4d.info.

K4D services are provided by a consortium of leading organisations working in international development, led by the Institute of Development Studies (IDS), with Education Development Trust, Itad, University of Leeds Nuffield Centre for International Health and Development, Liverpool School of Tropical Medicine (LSTM), University of Birmingham International Development Department (IDD) and the University of Manchester Humanitarian and Conflict Response Institute (HCRI).

This report was prepared for the UK Government's Foreign, Commonwealth and Development Office (FCDO) and its partners in support of pro-poor programmes. Except where otherwise stated, it is licensed for non-commercial purposes under the terms of the Open Government License v3.0. K4D cannot be held responsible for errors, omissions or any consequences arising from the use of information contained in this report. Any views and opinions expressed do not necessarily reflect those of FCDO, K4D or any other contributing organisation.

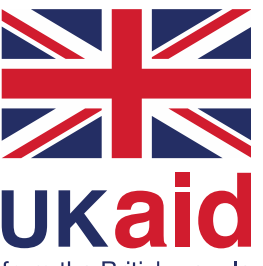

(C) Crown copyright 2021. 